\title{
Chapter 15 \\ Responsibility of Organized Armed \\ Groups Controlling Territory: Attributing Conduct to ISIS
}

\author{
Katharine Fortin and Jann Kleffner
}

\section{Contents}

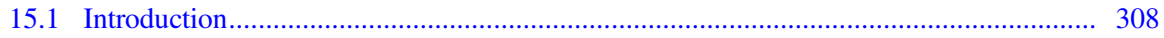

15.2 Brief History of the Rise and Fall of the Islamic State ......................................... 310

15.3 The Islamic State and IHL and IHRL ............................................................ 312

15.4 Need for Secondary Rules of Attribution .............................................................. 314

15.5 Applying State Responsibility by Analogy: Potential and Pitfalls ........................... 318

15.6 Attributing Conduct to the Islamic State .......................................................... 320

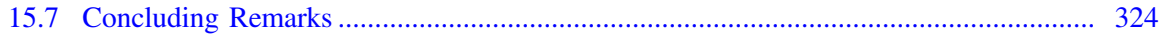

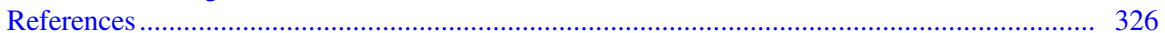

\begin{abstract}
In stark contrast to the situation for states, international organizations and individuals, there is no coherent international legal framework governing the responsibility of non-state organized armed groups that are parties to armed conflicts. The present chapter explores the possibility of developing such a framework for international law by focusing first on formulating a set of rules on attribution of conduct; and, second, using the Islamic State (IS) as a case study, to explore how some core rules of attribution could be applied to a specific type of organized armed group, namely those that - at least during a certain period of their existenceexercise territorial control.
\end{abstract}

The research assistance of Isak Malm is gratefully acknowledged.

K. Fortin $(\bowtie)$

Netherlands Institute of Human Rights, Utrecht University, Utrecht, The Netherlands

e-mail: k.m.a.fortin@uu.nl

J. Kleffner

Swedish Defence University, Stockholm, Sweden

e-mail: Jann.Kleffner@FHS.se

(C) T.M.C. ASSER PRESS and the authors 2021

R. Bartels et al. (eds.), Military Operations and the Notion of Control Under International Law, https://doi.org/10.1007/978-94-6265-395-5_15 
Keywords International humanitarian law $\cdot$ international human rights law $\cdot$ organized armed groups $\cdot$ territorial control $\cdot$ armed conflict $\cdot$ attribution $\cdot$ collective responsibility

\subsection{Introduction}

At present, international law does not provide for a well-developed and coherent set of rules governing the responsibility of non-state organized armed groups that are parties to armed conflicts. In stark contrast to states, international organizations and individuals, there is no legal framework addressing matters such as the attribution of conduct to such groups qua groups as collective entities, the legal consequences of responsibility, and possible 'defences' in the sense of circumstances that preclude the wrongfulness of acts in breach of international law that are attributable to such groups. Of course, states and other actors are far from inactive vis-à-vis organized armed groups and take a variety of measures addressed to them, such as imposing sanctions. Yet, these accountability measures are not accompanied by a coherent framework of responsibility grounded in international law.

The present chapter explores the possibility of developing such a legal framework. However, rather than engaging in a generic discussion on the desirability and possible design of international legal rules and principles governing the responsibility of organized armed groups as a broad category, ${ }^{1}$ our analysis is delineated in the following way. First, our focus will be on formulating a set of rules on attribution of conduct. Other aspects of a framework for responsibility are beyond the purview of the present chapter. Secondly, we will explore the issue of attribution in relation to a specific type of organized armed group, namely those that - at least during a certain period of their existence-exercise territorial control. Our considerations hence cannot necessarily be transposed to organized armed groups that fail to possess such control.

We will conduct that exercise inductively and channel our analysis through a case-study on an organized armed group that has featured in the academic work of Terry Gill, namely the Islamic State/Daesh. ${ }^{2}$ The Islamic State makes a useful case study, because the differences in its organisational structure, functions and size over the short years of its existence have been extreme. In its early years, it presented itself as just another armed group in the patchwork of what was estimated to be more than a thousand armed opposition groups fighting in Assad's Syria. But by 2014, it was exercising territorial control over an area twice the size of the

\footnotetext{
${ }^{1}$ For these, see e.g. Fortin 2017, pp. 277-279; Kleffner 2009, pp. 238-269.

${ }^{2}$ See e.g. Gill 2016; Gill and Tibori-Szabó 2020. Terry Gill also organized the launch conference of the LACMO Research Network on 'The Rise and Fall of ISIS' in Amsterdam in September 2018.
} 
Netherlands (i.e. around $88,000 \mathrm{~km}^{2}$ ) inhabited by $12-15$ million people. ${ }^{3}$ Today, the capacities of the Islamic State are vastly reduced, and its fighters have largely retreated to the deserts and mountains of Syria and Iraq. ${ }^{4}$ During the course of its life, the Islamic State not only grew and then shrank again, it also combined with other groups, who fought with it under different forms of allegiance. Some armed groups merged with the Islamic State, others simply adopted its logo and flags. Others declared that their acts were those of the Islamic State, with the latter at times endorsing those acts after the event.

The Islamic State had sophisticated governance structures, existed in different forms and fought under banners of allegiance with other groups, which makes it a robust and challenging case study to examine the difficulties of developing a set of secondary rules for organized armed groups broadly, and rules on attribution more specifically. Similarly, the history of the Islamic State's 'rise and fall' vividly highlights that any attribution regime developed for armed groups will need to take account of armed groups changing their shape over time. Equally, the case of the Islamic State invites us to reflect on the - admittedly at the time of writing somewhat speculative-possibility to hold an armed group responsible, after an armed conflict has ceased, when its legal personality (as an obligation bearer) has been extinguished, for instance because it has been comprehensively defeated or dissolved in the course of a peace process.

The fact that the Islamic State fought together with other groups, shows that it is also necessary to clarify the circumstances in which an armed group may be responsible for the acts of (members of) another armed group. Equally, affiliated groups - and individuals - have sometimes pledged allegiance to the Islamic State, either after an attack or before an attack, which requires a consideration of the significance of such pledges for the responsibility of the group allegiance is pledged to.

It is unclear how these questions should be answered, both from a lex lata and lex ferenda perspective. The purpose of this chapter is to evaluate how these difficulties play into an examination of the extent to which the rules on State responsibility pertaining to attribution can be applied by analogy to armed groups like the Islamic State. Drawing upon literature from the social sciences on the Islamic State and news stories, it considers whether the organisational realities of such a group make the application of these rules appropriate or workable.

The chapter briefly recounts first the history of the rise and fall of the Islamic State (Sect. 15.2) and the applicable primary rules that bind the Islamic State (Sect. 15.3). An analysis of the need for secondary rules on responsibility of organised armed groups follows (Sect. 15.4). The subsequent sections address the

\footnotetext{
${ }^{3}$ CNN (2019) ISIS fast facts. https://edition.cnn.com/2014/08/08/world/isis-fast-facts/index.html. Accessed 26 February 2020; BBC (2018) Islamic State and the crisis in Iraq and Syria in maps. https://www.bbc.com/news/world-middle-east-27838034. Accessed 26 February 2020.

${ }^{4}$ Abdulrahim R and I Coles (2018) Islamic State returns to guerilla warfare in Iraq. https://www. wsj.com/articles/islamic-state-returns-to-guerrilla-warfare-in-iraq-and-syria-1514889000.

Accessed 26 February 2020.
} 
suitability of applying the rules on state responsibility on attribution to the Islamic State by analogy (Sect. 15.5), followed by the actual application of the pertinent rules on attribution (Sect. 15.6). The last section offers some concluding observations.

\subsection{Brief History of the Rise and Fall of the Islamic State}

Although the Islamic State has its origins in the 2000s in Iraq, the legal analysis in this chapter focuses on the re-emergence of the group after the beginning of the non-international armed conflict in Syria in 2011. The Islamic State emerged as an actor in that armed conflict in 2013 under the leadership of Abu Bakr al-Baghdadi. ${ }^{5}$ In late 2013, the Islamic State was widely seen as just another armed group in the fight against the Assad regime in Syria. ${ }^{6}$ In the early years of its existence, when it was estimated that there were up to a thousand armed groups fighting in different alliances against the regime, the Islamic State often fought alongside other armed groups, in order to defend towns and strategic centres from advances by the regime. ${ }^{7}$ But the Islamic State quickly transformed itself into something different. ${ }^{8}$ Rapidly taking control of huge swathes of territory, it made it clear that its main priority was to establish a Caliphate that would cover a huge area of Iraq and Syria. ${ }^{9}$ Its new Caliph-Abu Bakr al-Bagdadhi-urged Muslims throughout the world to come and join the group, particularly "judges and those who have military and managerial and service skills, and doctors and engineers". ${ }^{10}$ The group's strength and territorial control reached the peak of its power in 2015, when it is estimated that between 10 and 15 million people lived under its control. At this time, the group controlled major urban centres such as Raqqa (which had around one million residents before IS took control) in Syria and Mosul (which had two million residents before IS took control) in Iraq. ${ }^{11}$ During the years that the group controlled these territories, the Islamic State developed a sophisticated bureaucracy in territory under control, with over 12 'diwans' (akin to ministries) covering issues pertinent to

\footnotetext{
${ }^{5}$ Stanford University 2019.

${ }^{6} \mathrm{BCC}$ (2013) Guide to the Syrian Rebels. https://www.bbc.com/news/world-middle-east24403003. Accessed 26 February 2020.

${ }^{7}$ Ukraine in Arabic (2014) Islamic State to form an alliance with the Jabhat al-Nusra. http://arab. com.ua/en/islamic-state-to-form-an-alliance-with-the-jabhat-al-nusra. Accessed 26 February 2020; Wikipedia 2019.

${ }^{8}$ Khatib 2015.

${ }^{9}$ Oosterveld and Bloem 2017.

${ }^{10} \mathrm{Al}$ Arabiya (2014) 'Caliph' urges skilled jihadists to join ISIS. http://english.alarabiya.net/en/ News/middle-east/2014/07/01/-Caliph-urges-skilled-jihadists-to-join-ISIS.html. Accessed 26 February 2020.

${ }^{11}$ Robinson et al. 2017.
} 
its governance project e.g. education, health, enforcement of public morality, public services, and agriculture. ${ }^{12}$

Studies on the Islamic State demonstrate that it deliberately provided public services in areas under its control not only to fulfil its aspiration of creating an economically prosperous Caliphate but also to protect and ensure its internal revenue. ${ }^{13}$ Unlike many other armed groups involved in the Syrian conflict, it is thought that the Islamic State was almost entirely internally funded. To secure its income, it relied heavily on directly taxing the population under its control, the imposition of social regulations and financial protection-schemes. According to US estimates, from 2016 onwards the group raised several hundred million dollars annually from these revenues. ${ }^{14}$ It also relied heavily on its control of natural resources, such as oil, natural gas and phosphates. In order to protect these revenue streams, it was important that economic life in the Caliphate continued in the towns where it had consolidated its control i.e. that markets remained opened and that people kept on buying and selling commodities. The group took steps to regulate every aspect of daily life, issuing landlines, pharmacy permits, fishing regulations and travel permits. ${ }^{15}$ It promulgated laws and regulations, which it used both to punish crimes connected to the armed conflict (i.e. prosecution of captured fighters, persons related to the regime, spies) and common crimes (e.g. witchcraft, possession of pornography, adultery, theft, fraud, murder, homosexuality). ${ }^{16}$ It frequently carried out cruel public executions, and displayed the bodies of convicted criminals in public places to communicate its lack of mercy and terrify the civilian population. ${ }^{17}$

As a fighting force, the Islamic State is said to have been organised similarly to a regular army, with many of its top leaders being former officers in Saddam Hussein's army in Iraq. ${ }^{18}$ After its split with Al-Qaida in February 2014, it continued to expand and carry out military operations in Syria and Iraq. From this time

\footnotetext{
${ }^{12}$ al-Tamini 2015.

${ }^{13}$ Robinson et al. 2017, p. xv.

${ }^{14}$ Ibid., p. xvi.

${ }^{15}$ al-Tamini (2017) Licensing exam for Islamic State pharmacists no cake walk. https://www. meforum.org/6696/isis-qualifying-exams-for-pharmacists-are-no-joke. Accessed 26 February 2020; al-Tamini 2015. See also Callimachi R (2018) The ISIS Files. https://www.nytimes.com/ interactive/2018/04/04/world/middleeast/isis-documents-mosul-iraq.html. Accessed 26 February 2020.

${ }^{16}$ Revkin 2016, p. 18.

${ }^{17}$ UN Human Rights Council (2014) Report of the Independent International Commission of Inquiry on the Syrian Arab Republic: Rule of Terror: Living under ISIS in Iraq, UN Doc. A/HRC/27/CRP.3, paras 32-36.

${ }^{18}$ The Washington Post (2015) Most of Islamic State's leaders were officers in Saddam Hussein's army. https://www.washingtonpost.com/world/most-of-islamic-states-leaders-were-officers-insaddam-husseins-iraq/2015/04/04/f3d2da00-db24-11e4-b3f2-607bd612aeac_graphic.html? noredirect=on\&utm_term=.c3bf49305a5e. Accessed 26 February 2020. See also Reuter C (2015) Secret files reveal the structure of Islamic State. https://www.spiegel.de/international/world/ islamic-state-files-show-structure-of-islamist-terror-group-a-1029274.html. Accessed 26 February 2020.
} 
onwards, the group was significantly organised with hierarchical command structure and both military and civilian shuras. One of the factors in its military successes is said to be linked to the fact that it contained fighters from several disparate conflicts, many of whom had earlier fought guerrilla wars. Its disparate membership and military capability enabled the group to shift between fighting as a conventional army and fighting as a guerrilla militia, employing different tactics according to the situation. ${ }^{19}$ Throughout its existence, the Islamic State regularly fought together with franchise groups that used its flags, logos and discourse but remained formally separate. $^{20}$ It also has regularly taken part in coordinated attacks with separate groups, such as its operations in Aleppo with Jund al-Aqsa. ${ }^{21}$ It also has many affiliates in third countries such as Afghanistan, Nigeria, the Philippines, Kenya, Tanzania, Uganda and Somalia. ${ }^{22}$ Towards the end of 2017, the Islamic State suffered a series of significant military defeats, losing control of much of its territorial control and abandoning urban centres. At the time of writing in early 2020, a vastly reduced Islamic State holds pockets of territory in Syria and Iraq. Hiding in isolated mountain or desert regions or among civilian populations, the group is now focusing on guerrilla tactics and sabotage tactics, rather than governance and administration. $^{23}$

\subsection{The Islamic State and IHL and IHRL}

There is every indication that the Islamic State fulfils the organisation requirement to be considered an 'organised armed group' as a party to a non-international armed conflict that has been set out in international case law. ${ }^{24}$ As from the time of its

\footnotetext{
${ }^{19}$ Barfi 2016.

${ }^{20}$ al-Tamini (2015) Talking to the Yarmouk Martyrs Brigade. https://www.newsdeeply.com/syria/ community/2015/10/13/talking-to-the-yarmouk-martyrs-brigade. Accessed 26 February 2020.

${ }^{21}$ Stanford University 2016.

${ }^{22}$ Warner 2017; Blanchard and Humud 2018. See also Noack R (2019) Bagdadi may be dead, but groups linked to Islamic State continue to pose threat in regions far and wide. https://www. washingtonpost.com/world/2019/10/28/baghdadi-may-be-dead-groups-linked-islamic-statecontinue-pose-threat-regions-far-wide/. Accessed 26 February 2020.

${ }^{23}$ UN Security Council (2017a, b) Twenty-fifth report of the Analytical Support and Sanctions Monitoring Team submitted pursuant to resolution 2368(2017) concerning ISIL (Da'esh), Al-Qaida and associated individuals and entities, UN Doc S/2020/53; Wright, R (2018) ISIS makes a comeback - as Trump opts to stay in Syria. https://www.newyorker.com/news/news-desk/ isis-makes-a-comebackas-trump-opts-to-stay-in-syria. Accessed 26 February 2020; Abdulrahim R and Coles I (2018) Islamic State returns to guerilla warfare in Iraq and Syria https://www.wsj.com/ articles/islamic-state-returns-to-guerrilla-warfare-in-iraq-and-syria-1514889000. Accessed 26 February 2020. See Flood 2018, p. 31.

${ }^{24}$ For a list of indicative factors for that requirement, see e.g. ICTY, Prosecutor v. Boškoski and Tarčulovski, Judgment, 10 July 2008, Case No. IT-04-82, paras 194-206. See, e.g., also ICC, Prosecutor v Ntaganda, Judgment, 8 July 2018, Case No. ICC-01/04-02/06, paras 704-715, ICC, Prosecutorv Bemba Gombo, Judgment, 21 March 2016, Case No. ICC-01/05-01/08, paras 134-136.
} 
entry into the armed conflict in Syria in 2013, it had a clear command structure, was able to carry out operations in an organised manner, had sophisticated logistics regarding military equipment, training and financing, a rigorous disciplinary system and a spokesperson. As of this time, the intensity of violence between the Islamic State and its opponents - the armed forces of Syria, the US and Turkey, several armed non-State actors, including the more moderate opposition groups, the Syrian Democratic Forces (SDF) and the Kurdish Peshmerga ${ }^{25}$ - has been such that there is little doubt as to the applicability of the law of non-international armed conflict. Since Additional Protocol II is inapplicable to the armed conflict(s) in Syria and Iraq, because both States have failed to ratify it, the Islamic State is bound by common Article 3 and customary international law of non-international armed conflicts.

A strong case can be made that human rights law is also applicable to the Islamic State. This is particularly the case in the years where it controlled huge swathes of territory and exercised governance functions. Many of the theories explaining how armed groups are bound by human rights law rely on a group's control of territory, asserting inter alia that an armed group inherits the international law obligations of the State in these instances. ${ }^{26}$ Equally, the additional value of human rights law vis-a-vis international humanitarian law in these circumstances is particularly clear, as human rights law is particularly well-suited to regulating the dynamics of everyday life that arise when armed actors perform functions of government in territory under their control. It has often been noted that human rights law contains a number of provisions that are entirely absent from international humanitarian law, such as a detailed provisions on the elimination of discrimination against women and protections of the right to freedom of expression, the right to freedom of movement, the right to freedom of association, freedom of religion and the right to health, in the sense of a right that extends to healthy people as well as the sick and the wounded. ${ }^{27}$ It also contains important legal provisions relating to the right to legal identity, including the right for children to be registered at birth, and their right to a name.

Human rights law also provides important provisions regarding law enforcement, which include rules governing the right to life, the right not to be arbitrarily detained and the right to a fair trial. These types of provisions are particularly important when scrutinising the daily life experienced by individuals living in territories and urban centres controlled by the Islamic State. Indeed, it has been argued that these provisions are particularly important when an armed group enforces laws relating to crimes with no obvious relationship to the armed conflict. $^{28}$ It can be noted in this regard that the Islamic State was assiduous at enforcing laws in territory under its control, promulgating a detailed set of criminal

\footnotetext{
${ }^{25}$ Ibid.

${ }^{26}$ See inter alia Clapham 2019, p. 11; Henckaerts and Wiesener 2020; Fortin 2017; Murray 2016.

${ }^{27}$ See Fortin 2016, pp. 169-170. See also Henckaerts and Wiesener 2020, p. 203.

${ }^{28}$ See Fortin 2016, pp. 177-179.
} 
laws relating to common crimes such as witchcraft, adultery, theft or homosexuality, pornography, selling or consuming drugs, alcohol or cigarettes. ${ }^{29}$ It is at least arguable that these prosecutions, detentions and arrests should also be assessed under human rights law, rather than (or in addition to) the law of non-international armed conflict. ${ }^{30}$ The idea that these law enforcement activities fall completely outside the scope of international humanitarian law is made less likely by the fact that the Islamic State deliberately integrated the imposition of appalling conditions of cruelty into its activities, as part of their military strategy. ${ }^{31}$

\subsection{Need for Secondary Rules of Attribution}

The present discussion about secondary rules on responsibility of the Islamic State and rules on attribution as part of them is to be understood against the background of a growing concern for the accountability of organised armed groups. Indeed, the absence of or lack of clarity in rules on responsibility has been suggested to constitute a 'gap' in the accountability regime for armed groups. ${ }^{32}$ The latter exists, for instance in the form of condemnations of violations and calls to cease them, the imposition of sanctions etc., thereby reflecting a growing concern for and relevance of organised armed groups as violators of international law. The corollary of the rise in, and recognition of, the power of organized armed groups to act in ways similar to states, is a limitation of states' responsibility for conduct of organized armed groups. It stands to reason that the resulting gap be filled by a legal regime for the responsibility of organized armed groups. ${ }^{33}$

Yet, there are currently no such legal rules providing guidance on how to attribute conduct to armed groups, or on the content and implementation of their responsibility, nor are there judicial or arbitral fora which can adjudicate the international responsibility of armed groups as such and hence could clarify with some authority the secondary rules that govern violations committed by them. Indeed, the lack of engagement with the issue in the practice of bodies that are called upon to document violations committed in the course of the armed conflict in Syria is instructive in this regard. The Independent International Commission of Inquiry on the Syrian Arab Republic has painstakingly documented these violations. In many of these reports, the violations of non-State armed groups are dealt with quite vaguely with allegations being loosely attributed to 'some anti-government armed groups' rather than being attributed to an identified and

\footnotetext{
${ }^{29}$ Revkin 2016, pp. 14-20.

${ }^{30}$ See Fortin 2016, p. 179. See ICRC 2019, p. 43.

${ }^{31}$ Ibid.

${ }^{32}$ Bílková 2015, p. 275. Bellal 2015, p. 285.

${ }^{33}$ See in this vein also Cahin 2010, pp. 332 and 335-337.
} 
named entity. ${ }^{34}$ The Commission's inability to pinpoint individuals' affiliation is likely explicable, at least in part, in the light of the intense fragmentation of the armed conflict. ${ }^{35}$ The Commission pointed out that the overlap in ideological orientation and political aspirations, as well as continuous personal and collective migration between groups made it difficult to 'draw linear or fixed lines of separation' between some of the Syrian opposition groups. ${ }^{36}$

However, it is symptomatic that the issue of attribution as a matter of law to the Islamic State in the Commission's reports remained to a large degree amorphous even when the Islamic State became more organised and controlled more territory, and the Commission increasingly dealt with its actions separately from the acts of other non-State armed groups, which continued to be dealt with collectively. ${ }^{37}$ In its accounts of the violations of international law by the Islamic State, the Commission makes little attempt to identify the roles of individual perpetrators (e.g. fighter, judge, bureaucrat) by the Commission. More often, the reports simply refer to 'ISIS' taking a particular action-whether it be carrying out an execution or committing someone to detention. In so doing, the Commission avoids an identification of the exact details as to the position of the perpetrator. Sometimes, the reports refer to 'ISIS fighters' however. ${ }^{38}$ In its November 2014 report on 'Living under ISIS', ${ }^{39}$ the Commission also did not seem to have particular difficulty in determining that particular actions of elements of IS' 'primitive but rigid administrative system, ${ }^{40}$ comprising the Al-Hisbah morality police, the general police force, courts and entities managing recruitment, tribal relations and education, could be attributed to ISIS when analysing the violations of international humanitarian law and human rights law committed by the group. ${ }^{41}$ And yet, while one can discern from such references that the Commission is of the view that acts of IS fighters and other 'organs' of that group can be attributed to IS, the reports are silent

\footnotetext{
${ }^{34}$ See UN General Assembly (2013) Human Rights Council: Report of the Independent International Commission of Inquiry on the Syrian Arab Republic, UN Doc. A/HRC/24/; UN General Assembly (2014b) Human Rights Council, Report of the Independent International Commission of Inquiry on the Syrian Arab Republic, UN Doc. A/HRC/25/65.

${ }^{35}$ See UN General Assembly (2013) Human Rights Council: Report of the Independent International Commission of Inquiry on the Syrian Arab Republic, UN Doc. A/HRC/24/46, para 14.

${ }^{36}$ Ibid., para 17.

${ }^{37}$ UN General Assembly (2014c) Human Rights Council: Report of the Independent International Commission of Inquiry on the Syrian Arab Republic, UN Doc A/HRC/27/60.

${ }^{38}$ See for example UN General Assembly (2014c) Human Rights Council: Report of the Independent International Commission of Inquiry on the Syrian Arab Republic, UN Doc $\mathrm{A} / \mathrm{HRC} / 27 / 60$.

${ }^{39}$ UN General Assembly (2014a) Human Rights Council: Report of the Independent International Commission of Inquiry on the Syrian Arab Republic, 'Rule of Terror: Living under ISIS in Syria', UN Doc A/HRC/27/CRP.3.

${ }^{40}$ Ibid., para 16.

${ }^{41}$ See, eg., ibid., para 49 for punishments carried out by Al-Hisbah and the all-female Al-Khans'aa brigade.
} 
on the issue of how and on what (legal) basis. This lack of determinacy undermines the legitimacy of accountability practices. ${ }^{42}$

It is further submitted that a clear legal framework for the responsibility of organised armed groups would fill an important void that currently exists between primary rules that are binding upon them qua groups, on the one hand, and a set of secondary rules that is reflective of their existence as collective entities, on the other. Clearly, quite a few primary rules in the field of international humanitarian and human rights law are applicable - either exclusively or in addition to individuals - to organized armed groups in their collective dimension. ${ }^{43}$ Not to devise a set of secondary rules on responsibility would thus fail to capture this important aspect of primary rules. This is not the least important to facilitate determinations of whether armed groups are violating their own commitments, enshrined within special agreements or unilateral declarations. Over the last twenty years, there has been an increase in these kinds of commitments. Notable examples are the Deeds of Commitment signed under the auspices of Geneva Call and the action plans agreed under the monitoring and reporting mechanism of the UN Special Representative on Children and Armed Conflict. ${ }^{44}$ Equally armed groups often commit themselves to humanitarian norms in the context of peace agreements. It is impossible to monitor an armed group's adherence to these types of agreements, if there are no clear secondary rules available to provide guidance, including on the issue of attributing conduct to the group.

In addition, organized armed groups provide the collective context in which violations that individuals commit occur. More often than not, the nature of such violations does not exhaust itself in the actions of individuals. Rather, these violations are embedded in a collective context that is the organised armed group. ${ }^{45}$ The current trend to reduce these groups to mere 'tools' of individuals ${ }^{46}$ does not do justice to the significance of the agency of organised armed groups. Indeed, this trend, which emphasises the role of individuals while downplaying the role of the organised armed group as a collective actor in its own right, brings to full circle the

\footnotetext{
${ }^{42}$ On the significance of determinacy for legitimacy, see Franck 1988, p. 713; Franck 1995, p. 30.

${ }^{43}$ See for example the judicial guarantees referred to in common Article 3 of the Geneva Conventions and Article 6 of Additional Protocol II which apply to armed groups in their collective dimension and cannot be fulfilled by individuals.

${ }^{44}$ For more information about Geneva Call's work, see its website https://www.genevacall.org/ what-we-do/. This lists the number of armed non-State actors that have signed its Deeds of Commitments protecting children in armed conflict, prohibiting sexual violence and gender discrimination, prohibiting attacks on health care facilities, personnel and medical transports and anti-personnel mines. Since the inception of the mandate, the Special Representative of the Secretary-General for Children and Armed Conflict has signed twenty-nine action plans with parties to non-international armed conflicts including armed groups. See UN General Assembly (2018) Annual Report of the Special Representative of the Secretary-General for Children and Armed Conflict, UN Doc. A/HRC/37/47.

${ }^{45}$ Kleffner 2009, pp. 238-269.

${ }^{46}$ The ICC's jurisprudence is indicative of such a trend, see e.g. Ntaganda 2019, above n 24, para 819 .
} 
assertion of the International Military Tribunal in Nuremberg in 1949 that '[c]rimes against international law are committed by men, not by abstract entities, and only by punishing individuals who commit such crimes can the provisions of international law be enforced'. ${ }^{47}$ Yet, we submit that capturing the phenomenon of violations committed by members of organized armed groups requires a holistic approach that addresses the individual and the collective dimension of such violations, rather than a mutually exclusive approach that focuses on the individual at the expense of the collective context in which s/he acts. Further support for such a holistic approach can be found in the fact that international criminal law suffers from two additional challenges, one legal, the other factual.

As to the legal, some violations of norms addressed to parties to a non-international armed conflict, including organised armed groups, do not constitute crimes governed by international criminal law. The 'mere' violation of the obligations on precautions in, and against the effects of attacks, which are applicable in non-international armed conflicts by virtue of customary international humanitarian law, ${ }^{48}$ are examples at hand. Another pertinent example is found in the prohibition of arbitrary detention in customary international humanitarian law, which does not constitute a crime in the Rome Statute. ${ }^{49}$ Whereas such violations could be addressed through the principles and rules of state responsibility, if committed by states, the absence of similar secondary rules pertaining to the responsibility of organised armed groups leaves a regulatory void. As to the factual challenge, only a fraction of crimes committed by (members of) organised armed groups are investigated and prosecuted, be it before domestic, internationalised and international criminal courts and tribunals. The efforts to investigate and prosecute crimes committed by IS-members are no exception in this regard. Despite notable steps to secure the criminal responsibility of Islamic State members, ${ }^{50}$ only a very limited number of domestic trials have been conducted, if considered against the scale of documented crimes. A framework for the responsibility of organized armed groups would make it possible to capture those violations that are not addressed through criminal proceedings.

The foregoing arguments demonstrate that a focus on secondary rules addressing armed groups as such is as much a factual necessity as it is necessary to fill a

\footnotetext{
${ }^{47}$ IMT, Judgment, 30 September 1946 and 1 October 1946 para 41.

${ }^{48} \mathrm{Cf}$. Henckaerts and Doswald-Beck 2005, Rules 15-20 and 22. The other rules on precautions (Rules 21, 23 and 24) are only 'arguably' applicable to NIAC's in the ICRC's assessment.

${ }^{49} \mathrm{Cf}$. Henckaerts and Doswald-Beck 2005, Rule 99 which states 'arbitrary deprivation of liberty is prohibited' in both international armed conflicts and non-international armed conflicts.

${ }^{50}$ See e.g. the International, Impartial and Independent Mechanism to Assist in the Investigation and Prosecution of Persons Responsible for the Most Serious Crimes under International Law Committed in the Syrian Arab Republic (IIIM), created by UN General Assembly (2016) Resolution 71/248, UN Doc. A/RES/71/248. See also the United Nations Investigative Team to Promote Accountability for Crimes Committed by Da'esh/ISIL (UNITAD), created by the UN Security Council (2017a, b) Resolution 2379, UN Doc. S/RES/2379.
} 
normative gap, to give a more solid conceptual foundation and methodological rigour to existing practices of holding armed groups to account for violations of the international norms that bind them.

\subsection{Applying State Responsibility by Analogy: Potential and Pitfalls}

In an attempt to devise a set of secondary rules governing the responsibility of organized armed groups for violations of the law of armed conflict and human rights law, two possibilities present themselves. One is to start with a clean slate and design such a set of rules from scratch without references to any established framework of responsibility. The other is to draw on those established under international law and explore whether and to what extent they can be transposed to organized armed groups. As to the latter possibility, those that have evolved in respect of collective entities - as opposed to individuals - would seem to be particularly suitable in light of the quest for devising a set of rules that are applicable to organized armed groups as such. The latter possibility would bring to the fore the rules and principles on the responsibility of states for internationally wrongful acts as a useful starting point. ${ }^{51}$

It is submitted that the second possibility is preferable. It is reflective of the fact that organized armed groups bear at least some resemblance to states and display state-like features to varying degrees. Indeed, the very fact that international law has evolved to recognize that rules of the law of armed conflict that were originally reserved for states in as much as they were limited to international armed conflicts, nowadays also apply in non-international armed conflict and hence bind organized armed groups, bears witness to the fact that organized armed groups and states share certain characteristics. Both entities bear legal personality and can occupy similar functional spheres relating to the conduct of hostilities and governance of everyday life. The gradual recognition that human rights law is binding on at least certain types of organized armed groups is also symptomatic of the fact that states and armed groups share some common features. ${ }^{52}$ Organized armed groups, much like states, command and exercise control over persons and at times also territory,

\footnotetext{
${ }^{51}$ While international law also provides a set of rules on the responsibility of international organizations, as codified in the Draft Articles on the Responsibility of International Organizations, see ILC 2011, these rules draw heavily on analogies with the law of state responsibility. It is therefore submitted that the latter rules are the more useful reference point also for exploring the possibilities of analogies for the present purpose of rules of responsibility for organized armed groups.

${ }^{52}$ Above, Sect. 15.3 .
} 
project policies which are formulated by 'an authority', and are in a position to project armed violence in the pursuit of their aims to a degree of intensity that reaches the threshold of an armed conflict. ${ }^{53}$

At the same time, any transposition of rules on the responsibility of states to organized armed groups needs to be approached with caution in recognition of the differences that do exist between states and organized armed groups. The latter do not have an internationally recognized right to exist in a legal system based on the sovereign equality of states that have the right to suppress organized armed groups on their territory. Furthermore, the law of state responsibility is devised to regulate the horizontal relation between states, i.e. between the state responsible for an internationally wrongful act on the one hand, and other states on the other hand. In contrast, a set of rules devised for regulating the responsibility of organized armed groups is not, or at least not primarily, concerned with the horizontal relation between different organized armed groups, but the vertical relation between states and organized armed groups or, for that matter, between individuals and organized armed groups. Last but not least, all states by definition share the features of statehood-a permanent population, defined territory, and effective government and the capacity to enter into international relations. Organized armed groups, in contrast, do share only the features of being 'organized', 'armed' and a 'group'. 54 Within those parameters, organized armed groups are very diverse, with some displaying more state-like features (such as control over population and territory through quasi-legislative, -executive and -judicial organs) than others. Indeed, organized armed groups regularly change over time and go through different phases during which they exhibit such features to varying degrees. That diversity and fluctuating nature of organized armed groups means, in turn, that the rules and principles of the law on state responsibility may be more appropriate to some (phases in the life of) organized armed groups than others. ${ }^{55}$ In the case of the Islamic State, the law of state responsibility may prove to be a more suitable point of reference during the period after its establishing its firm control over territory and persons in Iraq and Syria around 2014, and the setting up of institutions that ensued, peaking in 2015, up until the point at which the Islamic State lost such control and its bureaucratic structures were displaced. ${ }^{56}$

The aforementioned considerations need to be borne in mind when we now turn to an examination of whether and to what extent the rules on attribution in the law on state responsibility can inform the formulation of such rules vis-à-vis organized armed groups in general, and the Islamic State in particular.

\footnotetext{
${ }^{53}$ Kleffner 2009, p. 260.

${ }^{54}$ See Prosecutor v. Boškoski and Tarčulovski, n. 24 for criteria for determining whether an entity can be considered an 'organized armed group'.

${ }^{55}$ Kleffner 2009, p. 261. See also Fortin 2018, pp. 350-351.

${ }^{56}$ See supra nn 11-17.
} 


\subsection{Attributing Conduct to the Islamic State}

The law of state responsibility provides for a number of rules on how to attribute conduct to States. ${ }^{57}$ Thus, Article 4 ASR does so with conducts of 'organs' of the State, regardless of 'whether the organ exercises legislative, executive, judicial or any other functions, whatever position it holds in the organization of the State, and whatever its character as an organ of the central Government or of a territorial unit of the State.' There does not appear to be any good reason why such a rule of attributing conduct could and should not be applied by analogy to organs of organized armed groups as a matter of principle. Admittedly, it may be difficult to discern whether an entity is in fact an organ, since the central means to determine the matter in the law of state responsibility - namely the internal law of the Statemay be unavailable in the context of organized armed groups. However, it has been noted that a determination under Article 4 ASR as to whether an entity can be qualified as an 'organ' does not exhaust itself in a mere exercise in formalities as reflected in internal law. Rather, state organs can become such by virtue of practice. ${ }^{58}$ Furthermore, the conduct of persons, groups or entities can be attributed to a state on the basis of Article 4 ASR if it can be qualified as de facto organs, namely when they act 'in 'complete dependence' on the State, of which they are ultimately merely the instrument ${ }^{59}$. In the case of attributing conduct to IS, these three dimensions of how to become an 'organ'-by way of internal rules, by way of practice and by way of complete dependence - are all manifest. The Islamic State's internal rules and practices applicable to its fighters, their recruitment and remuneration, those governing entities endowed with the performance of executive functions, such as the Al-Hisbah morality police and the general police force, and those exercising judicial functions, as well as the rules and practices relating to the operation of 'diwans', suggest that the respective entities are 'organs' of IS whose conduct can be attributed to it. Indeed, this approach explains most plausibly the practice of the International Commission of Inquiry on Syria referred to above, in which acts of the aforementioned entities are attributed to IS. ${ }^{60}$ Over and above the creation of its own organs, IS also assumed control over parts of the pre-existing bureaucracy in Syria and Iraq, and ensured that they operated in complete dependence on it, ${ }^{61}$ providing good grounds to also attribute the conduct of such entities to it as de facto organs.

It is less straightforward to also apply Article 5 ASR by analogy to IS. The rule provides for attribution of acts of conduct of persons or entities which are not State

\footnotetext{
${ }^{57}$ ILC 2001, Articles 4-11.

${ }^{58}$ See ILC 2001, commentary to Article 4, para 11.

${ }^{59}$ ICJ 2007 (Bosnia Genocide case), 2007 ICJ Rep 43, para 392.

${ }^{60}$ See supra nn $38-40$.

${ }^{61}$ For a recount of that process of assuming control over the Iraqi Directorate of Agriculture, see Callimachi R (2018) The ISIS Files. https://www.nytimes.com/interactive/2018/04/04/world/ middleeast/isis-documents-mosul-iraq.html. Accessed 26 February 2020.
} 
organs under Article 4, but are empowered by the law of that State to exercise elements of the governmental authority, provided they are acting in that capacity in the particular instance. Yet, although there is no obvious reason to reject the possibility of finding guidance in the rule to organized armed groups in principle, subject to the necessary modifications as far as the notions of 'internal law' and 'governmental functions' are concerned, ${ }^{62}$ the specific case of IS would seem to render such an exercise less relevant. Whereas Article 5 is concerned with the outsourcing of governmental functions to private institutions, with the managing of prisons and immigration control as often-cited examples, ${ }^{63}$ the available facts do not seem to indicate that IS has engaged in analogous practices.

To the extent that entities cannot be qualified as 'organs' of IS in the sense above, the instruction, direction or control-test under Article 8 ASR can provide further guidance on how to attribute conduct to it. The potential relevance of these notions is demonstrated by the fact that the Islamic State has had different forms of relations, including coordinated military operations, with franchise groups that remained formally separate. ${ }^{64}$ The relationship between IS in Syria and Iraq, on the one hand, and IS in Libya, on the other is instructive in this regard. Some sources seem to suggest that IS in Libya was 'under the direct command and control' of IS' 'core operation in Iraq and Syria', chiefly through the presence and role of a commander by the name of Zubaidi, who headed the Islamic State operations in central Iraq prior to going to Libya. ${ }^{65}$ Some have taken the position that, if the group in Libya was sufficiently organized for the purposes of IHL, and its leadership was under the direct command and control of [IS] headquarters' it would suffice if the 'central leadership exercises factual command and control over the commanders of sub-groups or units, and the sub-group's leadership exercises operational coordination and strategic authority over its units' to consider the entire sub-group part of the overall organization. ${ }^{66}$ That position contrasts with an alternative view, which holds that all parts of the armed group would need to act under a centralized military command and a chain of command from top to bottom, in other words that a chain of command would run all the way from the IS leadership in Syria and Iraq to the IS rank and file in Libya. ${ }^{67}$

Admittedly, both views are expressed in the context of determining whether an armed group forms part of a transnational armed group that possesses centralized

\footnotetext{
${ }^{62}$ Kleffner 2009, p. 263.

${ }^{63}$ See, e.g., Momtaz 2010.

${ }^{64}$ See supra nn $20-21$.

${ }^{65}$ Chesney R (2015) The Global War on ISIL and Its Associated Forces. https://www.lawfareblog. com/global-war-isil-and-its-associated-forces. Accessed 26 February 2020.

${ }^{66}$ Rodenhäuser 2018, p. 100.

${ }^{67}$ Ambos and Alkatout 2012, p. 347.
} 
command structures so that both are considered as one, rather than the context of attributing conduct for the purpose of determining responsibility. What the difference in opinion brings to the fore for the purposes of the present analysis is, however, that IS in Syria and Iraq exercised 'direct command and control' over IS in Libya and the legal question whether the degree of such command and control can be considered sufficient for an attribution of the conduct of IS in Libya to IS in Syria and Iraq. Under the test of Article 8 ASR, the level of control that is required is subject to debate, with some holding that 'overall control' ${ }^{68}$ is sufficient, whereas others posit that 'effective control ${ }^{69}$ is required. The latter notion would restrict attribution to acts of a non-state organized armed group that is subject to control, which is not only equipped and/or financed, but its actions are also supervised by the State in question, and that the group also receives specific instructions from that State, or that the State controls the specific operation in the course of which the conduct in question occurred. 'Overall control', on the other hand, would let it suffice that, beyond equipping and financing the group, the State coordinates and helps in the general planning of its military activity, whereas it would not be necessary to also issue, either to the head or to members of the group, instructions for the commission of specific acts. If transposed to the attribution of conduct of one armed group to another, the difference between the two levels of control would mean that conduct of IS in Libya would only be attributable to IS in Syria and Iraq under the effective control test if the latter supervised the actions of the former and issued specific instructions, or controlled the specific operation in question in Libya. The overall control test would in contrast be satisfied already if it were established that IS in Syria and Iraq would coordinate and help in the general planning of the actions of IS in Libya.

One of the extra-ordinary features of the rise of IS has been that it has been accompanied by a series of 'pledges of allegiance' from armed groups around the globe, including Libya, ${ }^{70}$ Nigeria $^{71}$ and the Philippines, ${ }^{72}$ and from individuals. ${ }^{73}$

\footnotetext{
${ }^{68}$ ICTY, Prosecutor v. Dusko Tadić, Judgment, 15 July 1999, Case No. IT-94-1-A (1999), para 131. Although it is at times pointed out that the latter assertion is made in the specific context of classification of armed conflicts as either international or non-international when dealing with individual criminal responsibility for war crimes, which militates against a transposition from that area to the general law of state responsibility, we subscribe to the view, expressed so aptly by Condorelli and Kress 2010, p. 235.

${ }^{69}$ ICJ, Case concerning military and paramilitary activities in and against Nicaragua (Nicaragua v. United States of America), merits, 27 June 1986 (Nicaragua case) I.C.J. 14, para 115; Bosnia Genocide case 2012, above n 59, paras 392-393.

${ }^{70}$ Wikipedia 2020.

${ }^{71}$ BBC (2015) Nigeria's Boko Haram pledges allegiance to Islamic State. https://www.bbc.com/ news/world-africa-31784538. Accessed 26 February 2020.

${ }^{72}$ Straits Times (2016) ISIS officially recognises pledges of allegiance from militant groups in the Philippines. https://www.straitstimes.com/asia/se-asia/isis-officially-recognises-pledges-ofallegiance-from-militant-groups-in-the. Accessed 26 February 2020.

${ }^{73}$ Moore J (2015) Spiritual leader of Libya's biggest jihadi group pledges allegiance to ISIS. https://www. newsweek.com/top-judge-libyas-biggest-jihadi-group-pledges-allegiance-isis-320408. Accessed 26
} 
The question arises whether such pledges have, or should have, any bearing on the attribution of the conduct of those groups and individuals to IS, if unaccompanied by any of the factors that would result in an attribution of conduct of those pledging allegiance under the aforementioned notions of organ attribution or attribution in accordance with the instruction, direction or control-test. In the law on state responsibility, a possible construct in those instances would be attribution of conduct that is being acknowledged and adopted as a State's own. ${ }^{74}$ That regulation under Article 11 ASR contemplates a situation in which conduct is being adopted subsequent to its occurrence, rather than prospectively, and that cases of 'acknowledgment' and 'adoption' have to be distinguished from cases of mere support or endorsement. ${ }^{75}$ Making that distinction may not be easy, but as a general rule, the subsequent conduct or words of the State would need to be such as to justify the conclusion that the original conduct of the person or entity in question is, in effect, acknowledged and adopted as the State's own and that the acknowledgment and adoption must be clear and unequivocal, even though it might not necessarily be express, but can be inferred from the conduct of the State in question. ${ }^{76}$ At the same time, the intentions of the author of the conduct in question are irrelevant.

If applied to the Islamic State in Syria, unilateral pledges of allegiance by a certain group or individual would hence not, without more, render the conduct of such a group or individual attributable to IS. That can be different in those cases where IS has officially announced that it accepted those pledges of allegiance, as it did on several occasions, ${ }^{77}$ provided one can discern from such acceptances that IS unequivocally acknowledges and adopts the conduct of the group or individual in question as its own. That determination may be easier in the case of conduct of individuals who engaged in a one-off action, such as a terrorist attack, than in the case of groups. As to individuals, official reactions of the Islamic State to some terrorist attacks as announced through its Amaq news outlet sometimes leave little

February 2020. See for the case of Sayfullo Saipov Celona L (2017) Terror suspect in NYC truck attack pledged allegiance to ISIS: https://nypost.com/2017/10/31/terror-suspect-in-nyc-truckattack-had-pledged-allegiance-to-isis/. Accessed 26 February 2020. See for the case of Anis Amri: Withnall A (2016) Berlin attack suspect Anis Amri 'recorded video pledging allegiance to Isis': https://www.independent.co.uk/news/world/europe/berlin-christmas-market-attack-anis-amriisis-video-pledged-allegiance-milan-suspect-a7492636.html. Accessed 26 February 2020.

${ }^{74}$ Cf ILC 2001, Article 11.

${ }^{75}$ ILC 2001, p. 122 at 6.

${ }^{76}$ Ibid., at 6 and 9.

${ }^{77}$ See e.g. Straits Times (2016) ISIS officially recognises pledges of allegiance from militant groups in the Philippines. https://www.straitstimes.com/asia/se-asia/isis-officially-recognisespledges-of-allegiance-from-militant-groups-in-the. Accessed 26 February 2020. (Phillipines); CBS News (2015) ISIS accepts Boko Haram allegiance pledge. https:/www.cbsnews.com/news/ isis-accepts-boko-haram-allegiance-pledge/. Accessed 26 February 2020. (Boko Haram in Nigeria); Withnall A (2016) Berlin attack suspect Anis Amri 'recorded video pledging allegiance to Isis'. https://www.independent.co.uk/news/world/europe/berlin-christmas-market-attack-anisamri-isis-video-pledged-allegiance-milan-suspect-a7492636.html. Accessed 26 February 2020. (Anis Amri). 
doubt that the Islamic State acknowledges and adopts those attacks as its own, referring to individual perpetrators as 'soldiers of the caliphate', ${ }^{78}$ and praising, approving and endorsing their actions in hindsight. As to groups, at least the following issues need addressing in regard to accepted pledges of allegiance. First, the question arises whether an accepted pledge of allegiance can be construed as 'acknowledgment' and 'adoption' of the conduct of the group 'en bloc', i.e., the conduct in its entirety, or whether an 'acknowledgment' and 'adoption' need to pertain to more specific conduct, such as a specific operation of the group whose pledge of allegiance has been accepted. Second, as Article 11 ASR regulates situations in which conduct is acknowledged and adopted subsequent to its occurrence, the acceptance of a pledge of allegiance by a group would raise the question whether attribution also extends to conduct that occurs after the acceptance of the pledge of allegiance by the Islamic State, i.e. prospectively. Be that as it may, the construct of acknowledging and adopting conduct as its own in the law of state responsibility is a useful starting point in examining attribution to the Islamic State of conduct of groups and individuals who have pledged allegiance to it, in cases where conduct cannot be attributed in other ways.

\subsection{Concluding Remarks}

The above analysis has demonstrated the need to develop a legal framework under which conduct can be attributed to armed groups. The development of these rules would be instrumental in building the legitimacy of accountability practices. It would also fill an important void that has arisen between a growing set of primary rules that are binding upon armed groups on the one hand, and the lack of rules determining how conduct in breach of such rules can be attributed on the other. International criminal law cannot be the only tool at the international community's disposal to address the acts of armed groups, because its focus on individual criminal responsibility makes it poorly equipped to address the full measure of an armed group's collective power and agency.

To identify the need of a set of secondary rules on responsibility of organized armed groups is one thing; yet our analysis also shows that it is quite another to devise such rules. While analogizing with the law on State responsibility may be a useful starting point, the idiosyncrasies and diversity of organized armed groups and the oscillating attributes they display militate against a simple and wholesale transposition of the law of state responsibility in general, and its rules of attribution more specifically. Indeed, the case of the Islamic State amply demonstrates that an

\footnotetext{
${ }^{78}$ See e.g. Bearak M (2016) When ISIS claims terrorist attacks, it's worth reading closely: https:// www.washingtonpost.com/news/worldviews/wp/2016/07/26/when-isis-claims-terrorist-attacks-itsworth-reading-closely/. Accessed 26 February 2020; Chavez N and Alkashali H (2017) ISIS calls New York terror attack suspect a 'soldier of the caliphate'. https://edition.cnn.com/2017/11/03/us/ new-york-terror-attack/index.html. Accessed 26 February 2020.
} 
analogy may be more befitting the period during which it displayed the features of a quasi-state, and perhaps less befitting other periods. One can extrapolate from this case study that there is a convincing case to proceed by transposing at least some of the rules on attribution from the articles on State responsibility, including organ-attribution, attribution on the basis of the instruction, direction or control-test, and attribution of conduct acknowledged and adopted as its own when an armed group functions as a quasi-state.

The mentioned considerations that, in our view, should guide the development of rules on attribution, need also to be part of the broader quest for developing a law of responsibility of organised armed groups, including the regulation of issues such as reparations, damages, claims, and countermeasures. The rise and fall of the Islamic State illustrates the challenges that the law on the content and implementation of such a framework of responsibility face. These challenges do not only include the, mildly put, unwillingness of the Islamic State to engage in processes designed to determine its responsibility. It also includes the eventuality that the current campaign against the Islamic State (both military and non-military) results in its disappearance, and with it its existence as an entity against which responsibility can be implemented. In addition, one can reasonably expect some resistance to the idea that accountability measures directed against the Islamic State be subjected to a legal framework that curtails the policy options of States and international organizations. While all of these challenges need to be taken seriously, so should the consequences of leaving the issue of accountability of organised armed groups to politics alone. One of the key distinguishing features between governance by the Islamic State and legitimate governance is that the latter is founded on an idea of the rule of law, which entails that all actors are accountable to laws that are 'publicly promulgated, equally enforced and independently adjudicated, and which are consistent with international human rights norms and standards. It requires [...] adherence to the principles of supremacy of law, equality before the law, accountability to the law, fairness in the application of the law, separation of powers, participation in decision-making, legal certainty, avoidance of arbitrariness and procedural and legal transparency. ${ }^{79}$

To develop a legal framework of responsibility of organised armed groups is a pivotal step in building a system based on this idea of the rule of the law; one that the Islamic State so blatantly denies to those that are subjected to its reign of terror.

\footnotetext{
${ }^{79}$ UN Doc. S/2004/616 (2004) para 6. See also 'Uniting our Strengths', Report of the Secretary-General, UN Doc. A/61/636-S/2006/980 (2006).
} 


\section{References}

\section{Articles, Books and Other Documents}

al-Tamimi A (2015) The Evolution in Islamic State Administration: The Documentary Evidence. Perspectives in Terrorism 9(4): 117-129

Ambos K, Alkatout J (2012) Has "Justice Been Done"? The Legality of Bin Laden's Killing Under International Law. Israel Law Review 45(2) 341-366

Barfi B (2016) The Military Doctrine of the Islamic State and the Limits of Ba'athist Influence. CTC Sentinel Vol 9(2), 18-23

Bellal A (2015) Establishing the Direct Responsibility of Non-State Armed Groups for Violations of International Humanitarian Law: Issues of Attribution. In: Gal-Or N, Ryngaert C, Noortman M (eds) Responsibilities of the Non-State Actor in Armed Conflict and the Market Place. Brill, 304-322

Bílková V (2015) Establishing Direct Responsibility of Armed Opposition Groups for Violations of International Humanitarian Law? In: Gal-Or $\mathrm{N}$, Ryngaert $\mathrm{C}$, Noortman $\mathrm{M}$ (eds) Responsibilities of the Non-State Actor in Armed Conflict and the Market Place. Brill, pp 261-284

Blanchard C, Humud C (2018) The Islamic State and U.S. Policy, Congressional Research Service. https://fas.org/sgp/crs/mideast/R43612.pdf. Accessed 26 January 2020

Cahin G (2010) The Responsibility of other Entities: Armed Bands and Criminal Groups. In: Crawford J, Pellet A, Olleson S (eds) The Law of International Responsibility. Oxford University Press, pp 331-354

Clapham A (2019) Human Rights Obligations for Non-State Actors: Where Are We Now? In: Lafontaine F, Larocque F (eds) Doing Peace the Rights Way: Essays in International Law and Relations in Honour of Louise Arbour. Intersentia, Antwerp

Condorelli L, Kress C (2010) The Rules of Attribution: General Considerations. In: Crawford J, Pellet A, Olleson S (eds) The Law of International Responsibility. Oxford University Press, p 235

Flood DH (2018) From Caliphate to Cave: The Islamic State's Asymmetric War in Northern Iraq. CTC Sentinel Vol 11(8): 30-34

Fortin K (2016) The Application of Human Rights Law to Everyday Civilian Life under Rebel Control. Netherlands International Law Review 63: 161-181

Fortin K (2017) The Accountability of Armed Groups under Human Rights Law. Oxford University Press, Oxford

Fortin K (2018) How to Cope with Diversity While Preserving Unity in Customary International Law? Some Insights from International Humanitarian Law. Journal of Conflict and Security Law Vol 23(3): 337-358

Franck T (1988) Legitimacy in the International Legal System. American Journal of International Law 84(4): 705-759

Franck T (1995) Fairness in International Law and Institutions. Oxford University Press

Gill TD (2016) Classifying the Conflict in Syria. International Law Studies, 92(1):353-380

Gill TD, Tibori-Szabó K (2020) Twelve Key Questions on Self-Defense against Non-State Actors. International Law Studies 95(1): 467-505

Henckaerts JM, Doswald-Beck L (2005) Customary International Humanitarian Law. Cambridge University Press

Henckaerts JM, Wiesener C (2020) Human Rights Obligations of Non-State Armed Groups: An Assessment Based on Recent Practice. In: Heffes E et al (eds) International Humanitarian Law and Non-State Actors. T.M.C. Asser Press, The Hague, pp 195-227

ICRC (2019) Report on International Humanitarian Law and the Challenges of Contemporary Armed Conflicts, $33^{\text {rd }}$ International Conference of the Red Cross and Red Crescent, 9-12 
December 2019, https://rcrcconference.org/app/uploads/2019/10/33IC-IHL-Challenges-report_ EN.pdf, accessed 26 January 2020

ILC (2001) Articles on Responsibility of States for Internationally Wrongful Acts, https://legal.un. org/ilc/texts/instruments/english/commentaries/9_6_2001.pdf, accessed 26 January 2020

ILC (2011) Draft Articles on the Responsibility of International Organizations, https://legal.un.org/ ilc/texts/instruments/english/commentaries/9_11_2011.pdf, accessed 26 January 2020

Khatib, L (2015) The Islamic State's Strategy: Lasting and Expanding. Carnegie Middle East Centre. https://carnegieendowment.org/files/islamic_state_strategy.pdf, accessed 10 January 2020

Kleffner JK (2009) The Collective Accountability of Organised Armed Groups for System Crimes. In: Nollkaemper A, van der Wilt H (eds) System Criminality in International Law. Cambridge University Press, Cambridge, pp 238-269

Momtaz D (2010) Attribution of Conduct to the State: State Organs and Entities Empowered to Exercise Elements of Governmental Authority. In: Crawford J, Pellet A, Olleson S (eds) The Law of International Responsibility. Oxford University Press, pp 331-354

Murray D (2016) Human Rights Obligations of Non-State Actors. Bloomsbury

Oosterveld WT, Bloem W (2017) The rise and fall of ISIS: from evitability to inevitability, The Hague Centre for Strategic Studies. https://hcss.nl/sites/default/files/files/reports/The\%20Rise $\% 20$ and $\% 20$ Fall\%20of\%20ISIS.pdf, accessed 10 January 2020

Revkin M (2016) The legal foundations of the Islamic State. https://www.brookings.edu/wpcontent/uploads/2016/07/Brookings-Analysis-Paper_Mara-Revkin_Web.pdf, accessed 10 January 2020

Robinson E et al. (2017) When the Islamic State Comes to Town: The Economic Impact of Islamic State Governance in Iraq and Syria. RAND Corporation. https://www.rand.org/pubs/research_ reports/RR1970.html, accessed 10 January 2020

Rodenhäuser T (2018) Organizing Rebellion: Non-state Armed Groups Under International Humanitarian Law, Human Rights Law, and International Criminal Law. Oxford University Press

Stanford University (2016) Mapping Militant Organisations: Jund al-Aqsa. http://web.stanford. edu/group/mappingmilitants/cgi-bin/groups/view/669, accessed 10 January 2020

Stanford University (2019) Mapping Militants: the Islamic State. https://cisac.fsi.stanford.edu/ mappingmilitants/profiles/islamic-state\#text_block_18356, accessed 26 February 2020

UN General Assembly (2013) Human Rights Council: Report of the Independent International Commission of Inquiry on the Syrian Arab Republic, UN Doc. A/HRC/24/46

UN General Assembly (2014) Human Rights Council: Report of the Independent International Commission of Inquiry on the Syrian Arab Republic, 'Rule of Terror: Living under ISIS in Syria', UN Doc A/HRC/27/CRP.3

UN General Assembly (2014) Human Rights Council, Report of the Independent International Commission of Inquiry on the Syrian Arab Republic, UN Doc. A/HRC/25/65

UN General Assembly (2014) Human Rights Council: Report of the Independent International Commission of Inquiry on the Syrian Arab Republic, UN Doc A/HRC/27/60

UN General Assembly (2016) Resolution 71/248, UN Doc. A/RES/71/248

UN General Assembly (2018) Annual Report of the Special Representative of the Secretary-General for Children and Armed Conflict, UN Doc. A/HRC/37/47

UN Human Rights Council (2014) Report of the Independent International Commission of Inquiry on the Syrian Arab Republic: Rule of Terror: Living under ISIS in Iraq, UN Doc. A/HRC/27/CRP.3

UN Security Council (2017) Resolution 2379, UN Doc. S/RES/2379

UN Security Council (2017) Twenty-fifth report of the Analytical Support and Sanctions Monitoring Team submitted pursuant to resolution 2368(2017) concerning ISIL (Da'esh), Al-Qaida and associated individuals and entities, UN Doc S/2020/53

Warner J (2017) Sub-Saharan Africa's Three 'New' Islamic State Affiliates. CTC Sentinel Vol 10 (1): $28-32$ 
Wikipedia (2019) Yarmouk Martyrs Brigade, https://en.wikipedia.org/wiki/Yarmouk_Martyrs_ Brigade, accessed 26 February 2020

Wikipedia (2020) Islamic State of Iraq and the Levant in Libya https://en.wikipedia.org/wiki/ Islamic_State_of_Iraq_and_the_Levant_in_Libya\#Laws, accessed 26 January 2020

\section{Cases}

ICC, Prosecutor v Bemba Gombo, Judgment, 21 March 2016, Case No. ICC-01/05-01/08

ICC, Prosecutor v Ntaganda, Judgment, 8 July 2018, Case No. ICC-01/04-02/06

ICJ, Case concerning application of the convention on the prevention and punishment of the crime of genocide (Bosnia and Herzegovina v Serbia and Montenegro), Judgment, 26 February 2007 (Bosnia Genocide case), 2007 ICJ Rep 43

ICJ, Case concerning military and paramilitary activities in and against Nicaragua (Nicaragua $v$. United States of America), merits, 27 June 1986 (Nicaragua case) I.C.J. 14

ICTY, Prosecutor v. Boškoski and Tarčulovski, Judgment, 10 July 2008, Case No. IT-04-82

ICTY, Prosecutor v. Dusko Tadić, Judgment, 15 July 1999, Case No. IT-94-1-A (1999)

IMT, Judgment, 30 September 1946 and 1 October 1946

Dr. Katharine Fortin is a lecturer of public international law and human rights at Utrecht University's Netherlands Institute of Human Rights. Her research focuses on the legal framework applicable to non-international armed conflicts and the protection of civilians vis-à-vis armed groups. Her Ph.D. (cum laude) at Utrecht University was co-supervised by Terry Gill.

Prof. Dr. Jann Kleffner is professor of international law and the head of the Centre for International and Operational Law at the Swedish Defence University. He is also an extraordinary professor at the Faculty of Law of the University of Pretoria, South Africa. 